\title{
The Construction of Meaning Through the Visual Images and Written Texts in Nature Republic
}

\author{
Wendy Cynthia Gunawan \\ English Department, Faculty of Languages and Literature, Petra Christian University, Siwalankerto 121- \\ 131, Surabaya 60236, INDONESIA \\ Email: wendywcg31@gmail.com
}

\begin{abstract}
Advertisement is an important business tool that enables companies to promote their products, as well as delivering a message. In this research, I use Nature Republic posters entitled "Soothing Gel" and "Soothing \& Moisture Aloe Vera 90\% Body". I used qualitative approach in this research. Next, I use the theories of Multimodal Discourse Analysis for the first research question and Denotative and Connotative for the second research question. I aimed to discover what the meanings that are constructed through the visual images and how the meanings are supported by the written texts. Through the poster, Nature Republic is building the feelings of being beautiful, young, confident, natural, pure, and trustworthy to its consumers. In conclusion, Nature Republic is trying to make consumers believe in their products and deliver many values through its posters.
\end{abstract}

Keywords: Advertisement, marketing, poster, multimodal discourse analysis, denotation, connotation.

\section{INTRODUCTION}

Advertising is the attempt to influence the buying behavior of customers or clients with a persuasive selling message about products and/or services. In business, the goal of advertising is to attract new customers by defining the target market and reaching out to them with an effective ad campaign (Ward, 2018). Nowadays, advertising uses every possible media to deliver their message across the world. It can be via television, print (newspapers, magazines, journals, etc), radio, internet, sponsorships, posters, events, colors, sounds, visuals and even people (endorsements). An advertisement is a marketing tool. When people look at an advertisement, which consists of both visual images and written texts, both elements come into the consumer's eyes as something real. Advertising is one of the most frequent types of marketing tool that people find in everyday life. Advertising is an element of successful marketing; thus, it is very important. Posters are one of the real examples. People can find them everywhere. In the market, advertising is important to inform the consumers about the products or services. Thus, to achieve the goals of advertising, advertisers should know about the consumers' need to influence their mind that it's important.

This research analyzes some posters (advertisements) of a Korean beauty product. The Korean beauty product brand that is analyzed is Nature Republic. I analyze the posters of Nature Republic. Nature Republic is a famous Korean brand, which has been known in many countries, including Indonesia. This study is about the use of visuals in Nature Republic posters. In this case, we need to see the images, colors, focus, and positioning used in the posters. It goes through issues that are central to advertising and particularly the advertising discourse through the use of visual images and written texts. The application of the visuals in advertising is a case that requires a semiotic examination. This study examines how visual images construct meaning and how the written texts support the visual images in a poster. In order to analyze the poster, I use Multimodal Discourse Analysis (MDA). I need to see how the posters construct meaning for the consumers. This study chooses Nature Republic posters because Nature Republic is a famous Korean beauty 
product in Indonesia. However, people need to know what the posters want to show or what the message that is built through the visual images and written texts in the posters is. People need to know directly the product's benefits or maybe the ingredients, the superiority compared to another brand, and so on. The posters there are used to show more detailed explanations rather than on social media. Social media posters are usually used only for promotion. In this case, I choose Nature Republic products because it is made in Korea. Nowadays, Korean beauty is very famous, especially among women. Many women are very interested in Korean skincare and makeup brands because they are trends, nowadays. Everyone wants to look like Korean people who have beautiful, smooth, moist, and glow skin. Nature Republic is one of the Korean beauty products that are very famous in almost every country. They sell products with good quality and affordable prices. Nature Republic also uses natural ingredients from Korea, which increase people's interests in buying these products for their skin. Therefore, it is important for Nature Republic to make posters that can deliver the messages clearly and make people be willing to buy the products even more. The use of visual images and written texts in Nature Republic posters is very important to attract consumers because it helps consumers to understand the products. Those posters are analyzed using MDA to see whether the visual images there already construct the right meaning or not. The theories are used to see whether the images and texts are related or not to the message that they want to deliver to the consumers. In order to find out, I analyzed it using theories.

Thus, the connection between visual images and the written texts was important for this research study. The construction of meaning in the posters cannot be excluded from the factors that cause the success and failure of any advertisement. The meaning of the visual images in Nature Republic posters may not be well constructed and may cause misinterpretation. The visual images on all posters can be unrelated with the written texts. Therefore, Nature Republic should understand how the consumers actually comprehend their advertisements. They may improve the way they deliver their posters' messages to the public based on the consumers' interpretation patterns and give an impact on them. This research study is important to the public because advertisements are generally used for everybody and appear in our daily lives.

\section{Multimodal Discourse Analysis}

Quoting Halliday's, Paltridge writes that "much of the work in multimodal discourse analysis draws from Halliday's $(1978,1989$ a) social semiotic approach to language, a view that considers language as one among a number of semiotic resources (such as gesture, images, and music) that people use to communicate, or make meaning, with each other" $(2012$, p.170). Language, in this view, cannot be considered in isolation from meaning but needs to be considered within the sociocultural context in which it occurs. Multimodal discourse analysis, thus, aims to describe the socially situated semiotic resources that we draw in for communication (Paltridge, 2012, p. 170). Multimodal discourse analysis considers how texts draw on modes of communication such as pictures, film, video, images and sound in combination with words to make meaning. It has examined print genres as well as genres such as web pages, film and television programmes. It considers how multimodal texts are designed and how semiotic tools such as colour, image, focus, and positioning/place of elements contribute to the making of meaning in these texts (Paltridge, 2012, p. 169). Images have been given special attention in much of the work in multimodal discourse analysis. These images may include photographs, diagrams, maps or cartoons. Images, further, can be seen as having a grammar of their own. For example, the social relationship between an image and its consumers is strongly influenced by whether the subject in the image establishes eye contact with the consumers or not. Each of these possibilities can be seen as an example of mood, where eye contact can perhaps suggest a demand, whereas no eye contact might suggest an offer. The point of view, or perspective, of the image is also relevant. For example, a horizontal image suggests involvement as the consumers view is on the same level as the subject of the image. Quoting Feez, Iedema, and White, Platridge writes that "a high angle shot might suggest superiority and a low angle shot might suggest respect. Other meanings are conveyed 
through the distance of a shot (close vs. Medium vs. Long), color and focus of the shot and the extent to which the image in the shot aims to reflect reality, or not" $(2010$, p. 172). In order to answer the research questions that I stated in the previous chapter, I wanted to focus on MDA to analyze the visual images because it would be more effective to be analyzed using those theories. The theory was used to analyze the images, color, focus, and positioning of the advertisements (posters). It was used to see how the visual images construct meanings.

\section{Denotation and Connotation}

"Connotation and denotation are often described in terms of levels of representation or levels of meaning (Chandler, 2007, p. 139)." From this quotation, it explains that connotation and denotation play part in order to reveal the true meaning behind a sign. There is always meaning behind a sign even when we see just one sign, it can probably conceive numerous other meanings, which unconsciously relate to it. From denotation and connotation, audience is expected to take part actively in identifying and revealing the true meaning of a sign. Barthes' theory of denotation and connotation is the renewal or adopted version from Saussure's theory. Barthes saw that connotation produces illusion from the denotation and the signifier and the signified being identical, and that denotation is purely natural. Thus, connotation is generated from denotation and that denotation and connotation are the two levels in order to reveal the true meaning of a particular sign. Barthes stated that there are two steps of how denotation and connotation take place. The first order of revealing the meaning is rather straightforward and it refers to the reality or what is seen from a particular object; it refers to the denotation. Denotation is the definitional, literal, obvious or a common-sense meaning (can be seen or touch) of a sign (Chandler, 2007, p. 137). To make it simpler, denotative meaning is based on what the dictionary says. Then, it goes to the second level of revealing the meaning, which is connotation. Connotation is different from denotation. Whereas denotation is the literal meaning and based on what the dictionary says, a connotation is used to refer to the socio-cultural and 'personal' associations, it can be either the ideological, emotional (Chandler, 2007, p. 138). Through connotation, 'personal' here is not purely personal meanings. Personal meanings can be determined by the codes to which the interpreter has access to. Hence, at this level, the audience is playing a part by applying their social background as well as their knowledge related to the sign and it might depend on the interpreter's gender, age, ethnicity, or even point of view. The example of denotation and connotation can be seen from the meaning of the word "baby". The denotative meaning of a baby, based on the Oxford Dictionary, is a very young child. Meanwhile the connotative meaning of a "baby" could be someone whom you love so dearly or a nickname which you give to your boyfriend or girlfriend. As it has been explained above, one sign could probably conceive numerous other meanings, and that connotative meaning is not fixed and unstable. The connotative meaning usually depends on the culture, era, as well as the individual's experiences. I used denotation in order to know the basic or the literal meaning of the written texts since ones that can be interpreted literally are produced words by using Collins and Cambridge Dictionary as her resource. Then, she used the connotation to analyze the meaning behind the written texts and how they support the visual images in the posters.

\section{METHOD}

I decided to use a qualitative analysis method to analyze the posters of Nature Republic. I decided to use qualitative approach because it is the most suitable approach to be used. The data is in the form of images and texts of the product. There is no numerical data. The readers are people who already know the product and willing to buy. Thus, I used qualitative approach and analyzed it with the theory used. Furthermore, qualitative content analysis was used to analyze the meaning of a particular advertisement by describing its meaning in a systematic way. 
The sources of data are two advertisement posters from Nature Republic, chosen for this research. Nature Republic posters used in this study are "Soothing Gel" and "Soothing \& Moisture Aloe Vera 90\% Body" posters. All of the posters were taken in Nature Republic shops at Pakuwon Trade Centre (PTC), West Surabaya.

The data were collected from Nature Republic shop. Nature Republic posters use English language. In collecting the data, I went to Nature Republic shop at PTC, looked at the posters and took pictures. Nature Republic posters focus on showing the benefits when people use their products. Thus, in order to find how the meanings are constructed by the visual images and how the written texts in the poster support the visual images, I started to look for posters, which had some images and texts. The criteria for selecting the posters are the ones with images that are supported by the written texts rather than posters that only have a large picture or just written texts. The posters are seen by many people who really want to know the products rather than posters in streets that people just pass by and do not pay attention to. So, I chose posters from Nature Republic at PTC.

I decided to analyze how the visual images construct meanings in all of the posters. In order to answer that, I started to analyze by finding out how the visual images; such as images, colors, focus, and positioning construct the meaning. The first research question was analyzed using Multimodal Discourse Analysis.

I analyzed the written texts from all of the posters which had been taken. After that, she determined the keyword from the texts in posters. Then, she started to find the possible meaning by using Denotation and Connotation. As her source of definition, I used Collins and Cambridge dictionary. After that, she found the denotative and connotative meaning from both of the posters. She used them to answer the second research question.

\section{FINDINGS AND DISCUSSION}

In the findings and discussion, I has analyzed the data in order to answer both of the research questions along with the purpose of the study, which is to reveal the use of Multimodal Discourse Analysis in constructing the meanings through visual images in advertisements. Moreover, the methapor theory is used to reveal the hidden meaning to show how the written texts support the visual images in the posters of Nature Republic. I did it by analyzing each images in the posters to answer the first research question. Then, to answer the second research question, I analyzed it by using denotation and connotation theory. She analyzed the written texts to reveal denotative and connotative meanings in every written text. Then, visual images are supported by the written texts. I started to see the visual images from both posters which are supported by the written texts in order to answer the second research question.

\section{The Construction of Meaning through Visual Images}

This research was intended to find out how meanings are constructed through the visual images in Nature Republic "Soothing Gel" and "Soothing \& Moisture Aloe Vera 90\% Body" posters. Therefore, finding the construction meanings in the poster came first before I explained how the written texts support the visual images in the construction of meanings. Before I goes more indepth into the analysis for each page, below are provided explanations about the first poster of Nature Republic which is "Soothing Gel" poster.

The construction of meaning of aloe vera leaf is important as "aloe vera leaf" is the dominant visual image in the poster. Aloe vera leaf symbolizes the product itself because it is made of aloe vera. The construction of meaning of aloe vera involves Multimodal Discourse Analysis as the theory. MDA intends to show that meanings are conveyed through the distance of a shot (Close 
vs. Medium vs. Long), color, focus of the shot, and the extent to which the image in the shot aims to reflect reality or not (Feez, Iedama, and White, 2010, p. 172). In aloe vera, green color is very dominant, but it is not just because aloe vera is green. Green color in Asia is often use for something related with relaxation, because green color is believed to give a calming effect for those who feel stress (Hero, 2019). Green color in the Asia signifies calm which build a feeling of young and fresh. In Nature Republic poster, it focuses on a blur leaf of aloe vera and the green color as the backgrounds. The shot on the aloe vera leaf aims to reflect the reality that Nature Republic uses the aloe vera as the base of the product. Moreover, as described by BioMed Research, "the mucilage of aloe vera not only increases amount of collagen on wound site, but also increases transversal connections among these bands rather than creation of change in collagen structure and as a result accelerates wound improvement". Nature Republic products use aloe vera that can help the consumers skin to feel fresh, young, and increase the amount of collagen in their skin. So, they can feel beautiful. On the other hand, the focus of aloe vera leaf is blurry because in the visual images, the emphasis is more in showing the products rather than the aloe vera. Moreover, the natural atmosphere is created through the green color, combined with aloe vera image. The combination of green color and aloe vera image gives an impression that the users will feel young when using the product. Thus, meaning is constructed through the combination of words, pictures, and images. The natural here means that the products do not use any artificial ingredient. Consumers who use the products will feel young, and beautiful which is created through the green color combined with the aloe vera image.

The construction meaning of the images of waterdrop is important. "Water droplet and aerosolization play a role in human hygiene and health systems as well as in crop culturing. Prevention or reduction of splashing can prevent transmission of diseases between animals and plants and keep technical systems such as pipe or bottling systems free of contamination. Some higher plants use water or waterdrops to keep leaves free from dirt and pathogens" (Koch \& Grichnik, 2016, p.3). Nature Republic uses waterdrop to show that their products are pure. The meaning of waterdrops is reinforced by the transparent color. Denotatively, a transparent means pure, clean, and clear. The waterdrops in the picture are put on the aloe vera leaf. Also, Paltridge (2012, p. 170) states that meaning is constructed through some combinations. In this advertisement, the combination that creates meanings is from pictures and colors. The pictures are aloe vera leaf and waterdrops. In this part, the construction of meaning through MDA resource in the pictures signifies the purity and free contamination products which mean that they are safe for consumers' skin. The other MDA resource is in the green color. As what I stated in 4.1.1, the green color constructs the meaning of feeling young. Thus, Nature Republic intends to show the consumers that they can feel safe and young when they use Nature Republic.

The construction meaning of the product's cover images focuses more on the gel inside the aloe vera. The focus on the gel inside aloe vera intends to reflect the reality that their product ingredient is made from aloe vera gel. As described in Neutrogena article, "A gel usually has the appearance of a jelly, and is transparent. It looks like a cross between a solid and a liquid, but does not behave like either. Gels are actually closer to liquids than solids, because they are mostly water based. Gels are now commonly available, in both beauty products and medications. Gel is more quickly absorbed by the skin" (Johnson, 2017). Nature Republic focuses more on the gel because they want to deliver a skin product which can work fast for consumers' skin. It can absorb to the consumers skin quickly and give then a cool effect because its gel based product. Moreover, the image is put on the left side because people always read something from left to right as it is also the focus that Nature Republic wants to show. Thus, they put it on the left side of the product's cover. The other thing that is important is the color. Nature Republic uses white color as the background of their product's cover. In general, white represents truth and light, away from dirtiness. White symbolizes the starting point, the origin, and the root of things. Quoting Turner, DeLong \& Martinson write that, "as the anthropologist, white is the most basic symbol to human beings; indeed, white was favored in many cultural spheres who worshipped the sun" 
(2012, p. 127). However, it is understood that the preference of Koreans for white clothing for thousands of years is regarded as a distinct charasteristic of Korea. Moreover, quoting Geum, DeLong \& Martinson write that "the preference for white is considered as an implication of aesthetic consciousness toward cleanness, purity, humility, and deep religious belief that inspired devotion to the pure, natural, and nondecorative" (2012, p.127). The meaning of white color is purity (pure), clean, and natural. The feeling of purity in 4.1.2 is reinforced by the color used in this part, which connotes sterile or clean atmosphere. So, the sterile or clean atmosphere is created thorugh the white color. Nature Republic product is a unity of purity added with white color that strengthens the meaning. Consumers who buy the product will be convinced that the gel is sterile, clean, and pure. In this part, the semiotic resources, in the form of colors and image, signify the purity of Nature Republic product.

The construction meaning of the product's box which is just on the edge of the product's cover is important. Nature Republic mostly uses green color as its base color. The product's box uses green color, as I mentioned in 4.1.1, Green color in Asian gives a calming effect that which build the feeling of young. When this product's box is in line with the previous image and color which are aloe vera and green color, it reinforces the meaning of nature and youth in 4.1.1. Thus, the construction of the meaning does not just stop on the aloe vera image and color, but it is also reinforced by the green color in the product's box. Green color is very dominant in Nature Republic because it gives a purposeful meaning that the Nature Republic product gives the consumers feelings of natural and young.

The construction meaning of aloe vera trademark is very important. There are two Korean texts and aloe vera images in there. The first text is “캘리포니아산" which mean "from California". The second text is "알로에베라" which mean "aloe vera". The trademark "from California" does not mean that it is produced in California. "Coming from California" means that the type of the aloe vera used is 'California' aloe vera. It is important as it informs people that Nature Republic product uses California aloe vera. Nature Republic chooses California aloe vera because as described in Allure by Ginger King, a cosmetic chemist "However, it's now on prop 65 in California." Proposition 65, which added a specific version of aloe vera to its list in 2015, is officialy known as the Safe Drinking Water and Toxic Enforcement Act of 1986 and is intended to protect people from chemicals known to cause cancer. He also stated that "Aloe vera has long been regarded as a nice ingredient for healing and moisturization by folklore". The trademark there intends to gain consumers' trust. Nature Republic wants to show the consumers that their products' ingredient is safe. It can protect from chemical materials which are dangerous for some diseases such as cancer. Here, Nature Republic wants to show the consumers that their product's ingredients is like proposition 65 which is very safe and chemical free. So, when people use the product, they can feel confident that Nature Republic product that they are using is healthy, pure, and protective. Besides, it is free from contamination.

The construction meaning of aloe vera leaf in the "Soothing \& Moisture Aloe Vera 90\% Body" poster is important. Aloe vera leaf here has the same meaning as in 4.1.1. The color of aloe vera is green and the green color in the Obangsaek philosophy signifies youth. The meaning of the green color is already stated in 4.1.1. The difference is on the focus of the image. The focus of the image in this poster is on the top of aloe vera leaf. In Multimodal Discourse Analysis, the point of view, or perspective, of the image is important. For example, a horizontal image requests the consumer's involvement as the consumer's view is on the same level as the subject of the image. A high angle shot might suggest superiority. Therefore, since the image of aloe vera leaf is put on the top, it becomes the main focus. It might be interpreted that the superiority here means that the aloe vera chosen for the product's ingredient is of a superior quality. Superior quality means that it is chosen aloe vera or number one aloe vera. Therefore, the quality can be guaranteed for the consumers. Thus, the consumers can trust Nature Republic product. 
The image of aloe vera gel is also important as the aloe vera leaf. Aloe vera gel shows that the ingredients of the product is taken from the gel of the aloe vera. The transparent color here is the color of the gel and also the product's gel. Denotatively, the transparent color means pure, clean, and clear. The transparent color here creates an impression of a product without any contamination from chemicals since the aloe vera gel and the product's gel have the same color. Moreover, the shot of the picture is put as the background and the position is in the middle-below. As I mentioned in 4.1.6, the middle-upper shot shows superiority, while in this part, the aloe vera gel is put in the middle-below. The aloe vera gel is put below the aloe vera leaf to give the impression that the gel is exactly the extract from the aloe vera leaf. Thus, the color is transparent because Nature Republic intends to show that the product is clear and nothing is hidden, especially for the chemical ingredients, so that the consumers can truly see and believe. The consumers will get a pure product which is safe to use for their skin.

\section{The Construction of Meaning through The Written Texts that Support The Visual Images}

This research was intended to find out how meanings are supported by the written texts of Nature Republic "Soothing Gel" and "Soothing \& Moisture Aloe Vera 90\% Body" posters. Therefore, finding the hidden meanings of the written texts in the poster came first before I explained how the written texts support the visual images in the construction of meanings. Before I goes more in-depth into the analysis for each page, below are provided explanations about the first poster of Nature Republic which is "Soothing Gel" poster.

\section{The Construction of Meaning through The Written Text in Nature Republic "Soothing Gel" Poster}

As the second research question focuses on how the meanings in the visual images are supported by the written texts in the posters of Nature Republic, I found out how the written texts support the visual images. First, the words "Soothing Gel" which represent calmness and connote the feeling of relax support the meaning of "safe" in the visual images' analysis. The consumers will feel calm and relaxed if they believe that the product is safe to use. Second, the words "Real Aloe" which represent the truth and fact of Nature Republic product that can be trusted. Moreover, "Real Aloe" reflects the reality that Nature Republic product is trustworthy and credible. The words "real aloe" support the visual images meaning of aloe trademark which is free from contamination. The consumers can trust Nature Republic product because it is free from contamination. It helps to show Nature Republic's credibility. Third, the value that can be taken from "for Instant Hydration!" written texts is a product that can be used when our skin is dry and the product absorbs to the consumers' skin instantly. As the product is absorbed to the consumers' skin instantly, the product proves to be a protective product as what I explained in 4.1.5. The words "for Instant Hydration!" mean a "protective" product. Fourth, the words "aloe vera 92\%" mean that the soothing gel product truly uses $92 \%$ aloe vera's gel as the ingredients. It means that the product is truly made of aloe vera as their its ingredients. Fifth, "soothing \& moisture" represent calmness and connote the feeling of being relaxed and beautiful while using Nature Republic product. The words "soothing \& moisture" help construct the meaning in 4.1.1 which is beautiful. The consumers will feel beautiful and confident while using Nature Republic's product. Thus, the written text in "Soothing Gel" poster proves that the written texts are supporting the constructed meaning of the visual images which helps show the value that Nature Republic wants to share. The Construction of Meaning through The Written Text in Nature Republic "Soothing \&
Moisture Aloe Vera 90\% Body" Poster

As the second research question focuses on how the meanings in the visual images are supported by the written texts in the posters of Nature Republic, I found out that the written texts support 
the visual images. First, the words "Soothing \& Moisture" represent calmness and connote the feeling of being relaxed and beautiful while using Nature Republic product. "Soothing \& Moisture" help to support the meaning of beautiful and confident in the visual iamges of the poster. Second, the words "Refreshing moistfull body with aloe vera" have two key words which are "refreshing" and "moistfull". The meaning of "refreshing" and "moistfull" help to support the meaning of "young" in the analysis of the visual images of the product. Thus, the written texts and the visual images in Nature Republic posters support each other to help the construction of meaning.

\section{CONCLUSION}

By analyzing Nature Republic posters, I found out that the construction of meanings that Nature Republic tries to build is the feeling of beautiful, young, confident, natural, pure, and trustworthy. This construction of meaning is supported by the hidden messages that are taken from two advertisement posters. Each of the hidden messages is supported by several keywords which conceive connotative layer. Throughout the advertisement poster, Nature Republic is constantly showing the natural atmosphere through the green color. Those elements of nature and color that are used in the poster imply that Nature Republic truly uses nature as its base and primary ingredients. They also try to build an impression of trustworthy and credible products.

In addition to the denotative and connotative meanings that I found in supporting the construction of meaning, by using denotation and connotation, I noticed something more than messages. One instance that can be found is the message of "truth" which refers to the "real aloe" as something that Nature Republic gives in its products. Nature Republic knows that as a cosmetic brand, it is vital to treat the skin with products that are good for the skin and that do not irritate the skin. Thus, Nature Republic fulfills those hopes by using the natural ingredient, which is real aloe vera, as the main source of its products.

Through the first layer, which is the denotative meaning, I found that all of the written texts merely talk about the general meaning. However, it was not enough just to see the messages only through the first layer. Therefore, the second layer or the connotative meaning was needed in order to reveal the true message or value which could not be seen only by looking at the denotative meaning. Through the second layer, I found how Nature Republic projects its values of natural product with real aloe for instant hydration and dry skin in both posters. All of the visual image and written texts support each other in revealing the hidden messages and the construction of meaning in the poster of Nature Republic.

In conclusion, the visual images and written texts support each other and they show that actually Nature Republic is consistent in delivering their product. The consistency can be seen through the poster of Nature Republic itself. Even though the data were taken from two different posters, but they show the whole same concept and their visual images and written texts support each other.

\section{REFERENCES}

72 Marketing Definitions. (2011, March 29). Retrieved August 20, 2019, from Heidi Cohen: https://heidicohen.com/marketing-definition/

Chandler, D. (2007). Semiotics: the basics. New York: Routledge.

DeLong, M., \& Martinson, B. (2012). Color and Design. London, New York. States: Bloomsbury Publishing Plc.

Fernando, S. (2019). Insecurity and Self-Acceptance Portrayed in Samsung Galaxy A8 Advertisement "Lets You Be You": A Multimodal Analysis. DOI: 10.9744/katakita.7.2.260-268. 
Hashemi, S. A., Madani, S. A., \& Abediankenari, S. (2015, May 19) The Review on Properties of Aloe Vera in Healing of Cutaneous Wounds. Biomed Research International. Retrieved from https://www.ncbi.nlm.nih.gov/pmc/articles/PMC4452276/\#B38

Hero, T. (2019, April 23). Menarik! Filosofi Arti Warna dan Kesan yang Dibawanya. Retrieved from https://www.koalahero.com/serbaserbi/pesan-kesan-arti-warna/

Hornby, A. S. (2010). Oxford advanced learner's dictionary. New York: Oxford University Press.

Johnson. (2017). Gel vs Cream - What's the Difference. Neutrogena. Retrieved from https://www.neutrogena-me.com/beauty-and-skincare-tips/skincare/gel-vs-creamswhats-the-difference

Koch, K., \& Grichnik, R. (2016, August 6). Influence of surface structure and chemistry on water droplet splashing (p. 3). Retrieved October 5, 2019, from The Royal Society Publishing: https://royalsocietypublishing.org/doi/10.1098/rsta.2016.0183

Moriarty, S., Mitchell, N., \& Wells, W. (2009). Advertising \& IMC principles \& practice. Upper Saddle River: Pearson Education, Inc.

Paltridge, B. (2012). Discourse Analysis (2nd Edition ed.) (pp. 170-172). New York City, New York, United States: Continuum Publishing Corporation.

Violina, E. (2019). The Brand Essence of L'Occitane through Verbal and Visual Expressions in Its Advertisement Videos. DOI: 10.9744/katakita.7.1.1-5

Ward, S. (2018, December 15). Advertising and the Ways to Go About It. Retrieved from https://www.thebalancesmb.com/advertising-2947182\#target-market 